\title{
At Play in the Field of Dreams: Theorising Attitudes, Percep- tions and Practices of Law Students in conjunction with the Reflections of Early Career Commercial Lawyers
}

By Barry Yau, Senior Lecturer at ANU College of Law, Australian National University, Orcid: https://orcid.org/0000-0002-9511-0311

and David Catanzariti, Honorary Lecturer at ANU College of Law, Australian National University, 0rcid: https://orcid.org/0000-0001-9828-2111 ANU College of Law, Australian National University

\begin{abstract}
Australian law schools are tasked with forming students in their knowledge and understanding of the law, with many students aiming to fulfil their dreams of pursuing a legal career. Utilising Bourdieu's conceptual tools, this article considers whether aspirations of being "real lawyers" are significantly influenced by motifs of career success predominantly linked to an "elite" tier of law practice. The attitudes and perceptions of law students can also positively or adversely shape their career path amidst the information at play in the law school space. Drawing on qualitative data, we have applied Bourdieu's tools to understand undergraduate and practical legal training students' responses to notions of career accomplishment. This is contrasted with the reflections of early career commercial lawyers about their law school experiences. With comparisons to contemporary surveys and research on student services for law students, along with their wellbeing, the article reasons that the assorted ambitions of law students requires a law school environment promoting a more diversified perspective of "real law" and "real lawyering".
\end{abstract}

Keywords - Bourdieu, practical legal training, legal careers, real law, real lawyering

Acknowledgements: We thank Vivien Holmes, Alexandra Johnstone, Helen Rodriguez, Courtney Macintosh, Stephen Tang and Pam Foo for their valuable contributions to the research project. We thank Kristoffer Greaves for his insights on Bourdieu's theory. The research was partly funded by the ANU College of Law Small Grant Scheme.

Disclosure statement - No potential conflict of interest was reported by the authors.

License - This work is under Attribution-NonCommercial-ShareAlike 4.0 International (CC BY-NC-SA 4.0) https://creativecommons.org/licenses/by-nc-sa/4.0/ Suggested citation: Yau, B and Catanzariti, D, "At Play in the Field of Dreams: Theorising Attitudes, Perceptions and Practices of Law Students in conjunction with the Reflections of Early Career Commercial Lawyers", Law in Context, 37 (1): 114-133, DOI: https://doi.org/10.26826/law-in-context.v37i1.116

\section{Summary}

1. Part I: Introduction

2. Part II: Literature review and Bourdieu's tools

2.1 Cultural field

2.2 Capital

2.3 Habitus

2.4 Bourdieusian concepts in North America and the UK

3. Part III: Methodology and limitations

3.1 Recruitment

3.2 Data collection

3.3 Limitations

4. Part IV: Data analysis

4.1 Dominance and disposition: The law school space and student headspace
4.2 Cultural capital and habitus: Bodies in the crowd 4.3 Far from the madding crowd: Complicity and resistance

5. Part V Impact of the information gap

5.1 Symbolic violence: Taking the next drop

5.2 Language and symbolic power: Upstairs, Downstairs

6. Part VI Broadening career information to law students

6.1 "I wish that I knew what I know now, when I was younger."

6.2 "Always be a first-rate version of yourself, instead of a second-rate version of somebody else."

7. Part VII: Conclusion

8. References 


\section{PART I: INTRODUCTION}

\section{"Now is the winter of our discontent." Shakespeare, Richard III}

The original object of the research project encompassed researching the attitudes of undergraduate law students (LLB or JD students), practical legal training (PLT) students), ${ }^{1}$ and early career commercial lawyers (with five years or less of commercial law practice) towards the study and practice of commercial law. ${ }^{2}$ The objective also included researching the role of legal ethics in the study and practice of commercial law. The commercial law focus stems from our commercial legal practice background and the fact that commercial/corporate law $^{3}$ is the most common legal practice area for entry-level lawyers in Australia (Evers 2011, p. 27). The project was also prompted by the principal researcher's desire to comprehend student attitudes in the course of designing and convening Commercial Practice in the PLT program at the Australian National University (ANU). We also have an interest in understanding what motivates law students to pursue careers in commercial law. Nevertheless, we contend the research has currency across the legal profession.

The central focus of this article is the "information gap"4 in the law school environment and its impact on students and lawyers in their perceptions of "real law" and "real lawyers". The information gap emerged organically ${ }^{5}$ as a dominant and recurrent theme arising from the focus groups and semi-structured interviews in this research. The information gap symbolises the paucity of information within the law school environment concerning the true scope of job opportunities in the legal career market and beyond. The information gap is also a manifestation of the hierarchy of career paths promoted (covertly or overtly) in law school. At the outset of the research project, the information gap research theme was not apparent to us. However, it became a consistent theme of discontent amongst some of the research volunteers during the data collection phase, which commenced on a winter's night in Canberra in 2014 and ended over a year later. We will contend in this article that the information gap appears to unduly constrain some students' appreciation of the wider range of career opportunities which are available to them than those routinely touted at law school. In law student circles the information gap can also have the intended or unintended consequence of reinforcing constricted ideals of career success that gain credence from one cohort to the next. Some of the early career commercial lawyers, themselves representing an earlier generation of law students, stressed the importance of addressing the gap to give law students a more realistic and broader picture of career paths. Several of these lawyers highlighted their struggles with the lingering effect of the information gap on their sense of professional competence and worth. This points to the powerful influence of interests that are seemingly entrenched and continually active in the law school environment and beyond. These interests deploy various forms of capital (tangible and intangible) promoting (as is their right) an elite perspective of lawyering, void of powerful countering perspectives. The effect of these influences are so dominant that the research found that some students, proudly attesting resistance to elite influences, still accepted (and even sought to aspire to) the narrow ideal of career competency promoted in law school.

The phrase "with great power comes great responsibility" underlies our decision to analyse and present the research for this article by utilising the conceptual tools of French sociologist Pierre Bourdieu. Bourdieu's theory of the cultural field (Bourdieu 1984, p. 24) is an apt framework to analyse aspects of this research. Bourdieu's positioning of actors in this social space according to their economic, cultural and social characteristics helps, to an extent, make some sense of the paradigm where large and powerful law firms exert dominance in the law school environment to legitimise a certain notion of professional competence across the general student body. Bourdieu's tools will assist in understanding the relationship between students and these dominant law firms, who are responsible for promoting and preserving their corporate interests. This article will consider the responsibility some other actors (for example, academics) have in the law school space to raise students' awareness and impact of the "power-play" that attempts to shape notions of real law.

\footnotetext{
${ }^{1}$ Admission as an Australian lawyer requires completion of a law degree (LLB or JD) and an approved PLT course, see Hewitt (2015, p. 94).

${ }^{2}$ Ethics approval granted 24 December 2013 (ANU HREC Protocol: 2013/717).

${ }^{3}$ Corporate law is a subset of commercial law.

${ }^{4}$ A term coined by an LLB volunteer in one of the focus groups.

${ }^{5}$ Without prompting from the moderator/interviewer.
} 
Part II will explain Bourdieu's tools and its application to the research project, and compare it to the current research and insights into student support services and wellbeing in law. It will also provide a review of how international legal education scholars have utilized the French theorist's tools in their research on the power that large law firms wield amongst students in the law school space in Canada, the UK and the USA. Part III will present the methodology and identified limitations of our research project. Part IV will examine and analyse the data utilising Bourdieu's tools, and present the research outcomes regarding the information gap. We will seek to demonstrate how the information gap narrows the notion of real law and real lawyers. Part V will highlight the impact of the information gap on law students and early career commercial lawyers and the associated symbolism that Bourdieu articulated. Part VI will consider the realism of expanding the law school environment to promote a wider range of opportunities, giving students a higher level of awareness about their career paths relating to their ambitions and dreams. Part VII will conclude with the importance of keeping the dreams real for students aspiring to be real lawyers.

\section{PART II: LITERATURE REVIEW AND BOURDIEU'S TOOLS}

$$
\begin{aligned}
& \text { "0 this learning, what a thing it is!" } \\
& \text { Shakespeare, The Taming of the Shrew }
\end{aligned}
$$

During the data collection phase, it became apparent that each student, commencing their undergraduate law studies, discovers before too long (if they were not already cognisant of this upon enrolment), that they are in a very competitive field with their course colleagues. There is competition amongst students to obtain high grades, with failure to do so meaning missing out on the opportunity to even apply for a job with a major law firm
(Fisher 2015). In Australia, competition has increased significantly due to the number of big (or top-tier) firms - all specialising in corporate law ${ }^{6}$ - remaining largely constant over many decades (Pinnington and Gray 2007, p. 154). In contrast, schools have increased sixfold from 1960 to 2018 (Kritzer 2013, p. 455). ${ }^{7}$ The law student's path to securing a graduate position with a top-tier firm (or their global or medium-tier counterparts) usually commences by being selected in the firm's clerkship program (akin to an internship) which students take up during their undergraduate degree. The clerkship application process is very spirited. ${ }^{8}$ It is largely self-evident that, even taking into account students who have no interest in pursuing career opportunities with a top tier firm, ${ }^{9}$ an ever-growing number of future law students will fail in their quest to become graduate lawyers in top-tier firms. We contend the competitive environment for law students has not changed since our data collection ended in 2015. Law school continues to be perceived as an institution "structured to pump out high powered graduates for top-tier firms" amidst a "culture of competitiveness" that "breeds an environment hostile to emotional vulnerability." (Lane 2020, p. 43). ${ }^{10}$

The issue of student autonomy in determining career choices, which underlies the information gap, is prevalent in research and insights into the wellbeing of Australian law students since 2015 . Research by O'Loughlin et al into the psychological distress of first-year undergraduate law students at Monash University sought to understand students' perception of their studies and its impact on their future career paths (O'Loughlin et al 2020, p. 30). Whilst their research did not elicit issues about the direction students can take in pursuing a career beyond law school, Roberts provides relevant insight as a third year JD student at the University of Melbourne (Roberts 2020, p. 40). We support Roberts' assertion that autonomous learning is an important aspect of wellbeing, where students feel empowered to direct the things that they can control and be actively engaged in (Roberts 2020, p. 40). ${ }^{11}$

\footnotetext{
${ }^{6}$ As top-tier firms have large corporate clients and undertake big corporate transactions, they are sometimes referred to as "corporate firms" in this article. This also aligns with some of the volunteers using "corporate" in connection with top-tier firms

${ }^{7}$ As at June 2019, Australia has 38 university law schools, and two non-university law schools offering accredited law qualifications.

${ }^{8}$ Selection for clerkship does not guarantee a graduate position. Top-tier firms usually take around four times the number of clerks compared to anticipated graduate positions, perpetuating a further level of competition: "Legal clerkships: what are they, and why are they important?" 22 June $2015<$ http://youveenteredlawland.com/ legal-clerkships-what-are-they-and-why-are-they-important>>

${ }^{9}$ Students who choose not to pursue a clerkship with a top-tier/global firm, can still pursue a job with other law firms/organisations, through their graduate programs. Occasionally, a top-tier/global firm will offer a graduate position to someone who has not undertaken their clerkship program.

${ }^{10}$ Christian Lane, at the time of writing his article, was a fifth year Law and Arts student at Monash University.

${ }^{11}$ The University of Melbourne Law School was ranked the top law school in Australia in 2020: https://www.topuniversities.com/university-rankings/university-subjectrankings/2020/law-legal-studies
} 
We contend further that the autonomy of law students includes making informed choices about career paths, which can be adversely impacted by the competitive activity driven by law firms in the law school environment. We support Holland and Taylor's arguments that a law student's ability to see "multiple pathways for employment and career development" post-graduation is significant in addressing the information gap to the benefit of students (Holland and Taylor 2020, pp. 113, 117). We agree with their assertion that students be encouraged to adopt a "positive professional identity that links with their inherent values with a chosen career pathway." We will contend in this article that a student's identity can be shaped by the information available in law school.

The Student Experience Survey (SES) is a suite of Australian Government endorsed surveys for higher education that "covers the student life cycle from commencement to employment" (Quality Indicators for Learning and Teaching, 2020). Whilst the SES does not provide data about law students' career paths, it does provide quantitative data about the level of law students' satisfaction with "support services" which bundles support from "career advisors", along with enrolment systems, learning advice and health services. We acknowledge that the SES survey of law students' satisfaction of support services (especially careers advice) is not quite analogous to their satisfaction of the career information made available to them in the law school space. However, the most recent survey, which draws upon data collected in 2018-2019, provides (even tenuously), a contemporary insight into the attitudes of law students towards the value of career information.

All but one of the law students who participated in our research were enrolled at ANU, which also happens to be a member of the Group of Eight, a coalition of research-intensive universities in Australia. ${ }^{12}$ For comparative purposes, and to highlight the relevance of our own research findings to law schools in largely populated cities in Australia, we compare our research findings with undergraduate law student satisfaction at Group of Eight universities towards support services. ANU law students gave a $61.2 \%$ positive rating of support services. Their counterparts at these universities provided positive ratings of: $50.7 \%$ at the University of Sydney, $55.9 \%$ at the University of New South Wales, and $67.7 \%$ at Monash
University. Undergraduate law students at the University of Adelaide and the University of Queensland provided a positive rating of $79.6 \%$ and $71.8 \%$, respectively. ${ }^{13}$ The ratings given by undergraduate law students at ANU, the University of Sydney, the University of New South Wales and Monash University were significantly less than the national average of $72.1 \%$ (the University of Melbourne achieved a positive rating of $72.9 \%$ for support services for their JD program, officially categorised as a postgraduate degree, as they no longer offer a LLB - this compares to the national average of $68.9 \%$ from students in law postgraduate programs). We cannot say to what extent a perceived lack of support from careers advisors comprised the relatively low ratings from undergraduate law students at ANU, the University of Sydney, the University of New South Wales and Monash University, as the SES data did not drill down to that subset. However, the significance, even if tenuously, of these statistics at the very least resonate with our research data, which may be relatable to law schools located in Australia's two largest metropolitan cities where the top tier firms have their biggest presence (the University of Sydney and the University of New South Wales are in Sydney, ${ }^{14}$ and Monash University is in Melbourne).

In light of this, we are drawn to applying Bourdieu's tools to examine the law school environment where distinctive powers (which include top tier firms) drive competitive activity, giving problematic rise to the information gap which impacts on law school students and beyond.

\subsection{CULTURAL FIELD}

Bourdieu's theory of a "cultural field" is akin to the law school environment. Bourdieu defined, in analytical terms, the cultural field as a "network or a configuration, of objective relations between positions". It is a "space of conflict and competition" conserving or transforming the structure of relational forces constituting the field (Bourdieu and Wacquant 1992, p. 17). The existence of positions are objectively defined by what they impose on the field's actors - "occupants, agents or institutions" - based on the structure of the distribution of power (or capital) whose possession commands access to the specific profits at stake in the field (Bourdieu and Wacquant 1992, p. 97). Dezalay and Garth have focused on

\footnotetext{
${ }^{12}$ The Group of Eight comprises the University of Sydney, the University of Melbourne, the University of Queensland, the University of Adelaide, the University of Western Australia, Monash University, the University of New South Wales and the Australian National University <https://go8.edu.au/>

${ }^{13}$ There was no rating amongst law students for support services at the University of Western Australia due to the number of survey responses being too low.

${ }^{14}$ ANU is a three hour drive from Sydney.
} 
analysing legal fields (for example, international commercial arbitration (Dezalay and Garth, 1996) and Asian legal systems (Dezalay and Garth 2012)) through the lens of Bourdieu, postulating that an analysis of a legal field involves examining "issues of power and hierarchy" that are inbuilt in the field (Dezalay and Garth 2016, p. 4). Dezalay and Garth's sociological approach to the legal field defines the field as a conceptual tool to explain social change and stability (Dezalay and Garth 2016, p. 4). Bourdieu's "sociology of fields" has been adopted to research differences in the hierarchy of the legal field that is characterised as semi-autonomous spaces comprising "rules of the game and actors oriented to the stakes of particular fields." (Dezalay and Garth 2016, pp. 2, 3). The actors in this social space, positioned according to their economic, social and cultural characteristics (Anheier et al. 1995, p. 860), are assumed to compete for social positions giving rise to social structure. The actors are also placed to shape or reform institutions in the field in relation to the power and capital the actors represent (Dezalay and Garth 2016, p. 4). In our research, the law school environment represents a social topology where we analyse the relative positions and objective relations between these actors (Bourdieu 1989, p. 16), invariably comprising law students, the law students' society (LSS), and faculty staff. Other actors, such as law firms who possess the necessary capital (for example money, human resources, status), are invited to exert their influence within the cultural field. Bourdieu draws an analogy to "aces in a game of cards, in the competition for the appropriation of scarce goods" in the social space (Bourdieu 1989, p. 17).

\subsection{CAPITAL}

Within this social space the fundamental powers are economic capital (in its different forms), cultural capital, and social capital (Bourdieu 1989, p. 17). These species of capital assume the form of symbolic capital when they are "perceived and recognized as legitimate" (Bourdieu 1989 , p. 17), that is legitimizing social class and social importance (Webb et al. 2002, p. 152). This becomes relevant in the way prized job offers, from top-tier firms, are seen as the culmination of a very competitive card game in the law school space. Our research points to students struggling to achieve the field's perception of success which, according to Bourdieu, symbolic relations of power tend to reproduce. The offer of a top-tier position as a symbol of high achievement and prestige reinforces the power and hierarchal relations constituting the structure of the social space. Bourdieu argues that the legitimation of such symbols is not the product of a deliberate and purposive action or symbolic imposition. Rather, it results from the fact that powerful agents in the social space (for example law firms partnering with the LSS) apply the structures of the social space to deal the aces that create a perception and appreciation that their picture of the world is evident. These agents, through their distribution of capital, can determine a hierarchy of legal practice that is favourable to them because of their de facto monopoly (Bourdieu 1989) of career information in the law school environment.

\subsection{HABITUS}

Our research identified the deployment of linguistic phrases to impose symbolic dominance as critical in reinforcing perceptions favoured by top tier firms within the law school space. Bourdieu theorised a "whole dimension of authorized language" including its syntax, exists "purely to underline the authority of its author and the trust he demands" (Bourdieu 1991, p. 76). Dominant actors such as top tier firms are experienced in deploying terminology from their deck of cards to maintain their ex cathedra advantage in the social space. We submit that these repetitive terms become the dialect of law students, even if some disavow the thought of a career with these firms.

\subsection{THE BOURDIEUSIAN INFLUENCE IN NORTH AMERICA AND THE UK}

Our research indicated a perpetuation (and even infatuation) of the notion of top-tier firms holding high prestige and status, even amongst some students who refuse to play the top-tier game in the social space. Bourdieu's concept of "habitus" may go some way to make sense of the acceptance of this view in the social space. Habitus refers to the part-conscious "taking in" of rules, values and dispositions, which adapts and installs itself within the social space through "regulated improvisations" (Bourdieu cited in Webb et al. 2002, p. 36). To Bourdieu, habitus is a dual system: one being a scheme of production of practices, and one being a system of perception and appreciation of practices (Bourdieu 1989, p. 19). Habitus therefore implies a "sense of one's place" and a "sense of the place of others" (Bourdieu 1989, p. 19). Bourdieu's habitus - "the feel for the game" (Bourdieu 2004, p. 597) - is a pattern of dispositions, practices and inculcated values recognised by individuals as a requirement to play (Pinnington and Gray 2007, p. 154; Cook et al. 2012, p. 1748). For Bourdieu, habitus can only function effectively 
if students lack awareness about what Bourdieu calls "the forgetting of history which history itself produces." (Bourdieu 1977, p. 78).

Our research fills a gap in the literature about the impact of the information gap, through a Bourdieusian lens, on law students in Australia. However, relevant to our research to varying degrees is literature from legal education scholars in North America and the UK that has applied Bourdieu's tools to the activity and influence of law firms on law students. Their research was conducted in the first decade of the $21^{\text {st }}$ century, possibly reflecting the global resurgence of Bourdieu's theories outside of France (Truong and Weill 2012). Their research covered a range of aspects relating to law firm recruitment practices, student identity, perceptions of lawyers, and career aspirations - all pertinent to the research in this article. Manderson and Turner's ethnographic study at Canada's McGill University explores, through a Bourdieusian framework, the conscious and subconscious impact of major law firms on law students in a university ranked in the top 50 of the QS World University Rankings (all but one of the law students in our research were enrolled at $\mathrm{ANU}$, also in the top 50 of these rankings). ${ }^{15}$ Bourdieu's "thinking tools" (Wacquant 1989, p. 50) such as habitus were utilised, in part, to research the transformation of Canadian law students' identities in a social space sponsored by major law firms (Manderson and Turner 2007, p. 649). This space was the "Coffee House", a weekly social event at McGill University's Faculty of Law, specifically:

during the recruitment period that consumes many final-year law students throughout January and February, major law firms from Montreal, and even Toronto, aggressively compete to "sponsor" Coffee House. In exchange for a prominent presence, the law firms supply waiters and live music, free food and - rather more to the point - free drink, at a cost of $\$ 5,000$ to $\$ 10,000$ per week (Manderson and Turner, p. 650).

Manderson and Turner's categories of participants was wider than our research cohort, with the Canadian team conducting over 80 informal, unstructured interviews with attendees at 10 Coffee Houses held during 2005, six of which were sponsored by major law firms. The attendees comprised law students, lawyers, academic staff, and waiting staff. The team also held semi-structured interviews at other times with key informants such as members of the Law Students' Association and some law professors. Habitus was explored to explain how McGill's law students' identities and educational aspirations were transformed even if these students insisted at the time that nothing was going on. Through the Coffee House, student identity was developed through performances and the accumulation of symbolic capital until students felt their future career path was their destiny rather than a matter of choice (Manderson and Turner 2007, p. 649). In contrast, some of the students in our research recounted that whilst major law firms had a dominant presence in the law school space through sponsorship and recruitment activities, it was not laden with lavish entertainment that occurred with regularity at McGill University's Law Faculty. Another point of dissimilarity with Manderson and Turner's study is that most of the law students in our research did not consider a career with a major law firm as their destiny. However, in our research some of the students' perspectives about the pinnacle of career success was shaped by the notions of career success promoted by major law firms in their law school environment. We concur with Manderson and Turner's finding that even if law students underwent a personal unconscious transformation through the repetitious influence of major law firms in the law school space, there still existed opportunities for changing the meaning of the social space and the performances (Manderson and Turner 2007, p. 649). We will later on in this article detail how the law school space can be transformed for the benefit of the broader law student community.

In the UK, Sommerlad took a longitudinal and sociological approach by researching:

professional identity formation, at both the individual and organizational levels, and the dialectic between individual processes and the social trajectory of organizational reproduction (Sommerlad 2007, p. 190).

Through Bourdieu's social analysis, Sommerlad surveyed legal practice course (LPC) students at an unnamed "new" university ${ }^{16}$ in a large UK provincial city. This is similar to our research whose participants included PLT students (equivalent to LPC students), although Sommerlad's collection of data, which commenced in 2004, is more layered, as she surveyed two cohorts of part-time and full-time

\footnotetext{
${ }^{15}$ QS Top Universities Ranking https://www.topuniversities.com/university-rankings

${ }^{16}$ A university established in post-1992.
} 
LPC students. ${ }^{17}$ Sommerlad's objective was to track the development of career aspirations, perceptions of the legal professional field, and levels of attainment (Sommerlad 2007, p, 196). A significant aspect to Sommerlad's research in contrast to our study is the social class and ethnic profiles compiled from the students (for example gender, working class, Asian British, Black and Ethnic Minority) to inform her research through the Bourdieusian framework. Our research did not formally seek this level of detailed background information from the law students and lawyers volunteering in the study (apart from their gender, legal work experience history, and in the case of PLT students and lawyers the university where they obtained their LLB or JD). Whilst the law students (particularly females) in our research provided responses influenced by their gender, issues of social class or ethnicity did not arise in the focus groups or semi-structured interviews. ${ }^{18}$ Whilst Sommerlad's in-depth research did not reveal the LPC students' exposure to the recruitment activities of law firms in the law school field, it did highlight the close links some firms had with select universities (Sommerlad 2007, p. 205). The encounters the students in our research had with the recruitment activities of top-tier firms in the law school space and the firms' influence on students' perceptions of legal practice is relevant to Sommerlad's insights into Bourdieu's cultural capital. ${ }^{19}$ Sommerlad's finding that the legal profession, especially at the elite level, remained largely closed to "outsider lawyers" (for example, Black and Ethnic Minority graduates and those with working-class backgrounds) resonates with our research. In particular, the information gap has a powerful influence on shaping the perceptions of law students about the hierarchy of Australian legal practice, in effect ranking top tier firms as being superior to the rest of the legal profession.

Utilising Bourdieu's theories, Jewel, in her lengthy essay, researched the issue of class as it relates to legal education. Through the Bourdieusian lens, Jewel examined these class differences with reference to the capital that law students and lawyers possess (for example, social, cultural, economic and symbolic capital) (Jewel 2008, p. 1156), noting:

in Bourdieusian terms, the myth of merit creates a habitus that causes law students to internally arrive at individual expectations and goals based on the legal profession's existing hierarchy...Within large firms, graduates from top schools are more likely to perform high-prestige work that focuses on securities and general corporate law, whereas graduates from lesser schools will specialize in lower-status work such as personal injury defence, family law, or general practice (Jewel 2008, pp. 1185, 1194).

We concur with Jewel's proposition that a perceived lack of credentials thwarts many law graduates of some law schools from starting their career in commercial or corporate law practice. ${ }^{20}$ However, we differ with Jewel's assertion that "a career in public service" is equally prestigious as a corporate law practice due to the credentialed prestige of US government sector positions (Jewel 2008, p. 1205). Our research highlights that amongst many law students in Australia, careers in top-tier firms are considered to be of higher prestige than most government practices. Where Jewel's research is very pertinent to our research is her observation of the devaluation of the career plans of law students "shut out" (for lack of suitable capital) from "high-status" jobs. Jewel identifies the complicity of the vast majority of law teachers in the USA whose background in elite educational institutions created a gulf between the experiences of law-status students and the experiences and expectations of their teachers (Jewel 2008, p. 1206). Jewel's recommendation to recognise a broader range of career trajectories as of equal value with "high-status" jobs (Jewel 2008, p. 1209) is endorsed by this article as a consequence of the influence large corporate firms wield in the law school field.

We contend our research contributes to the body of literature with its focus, through a Bourdieusian lens, on top tier recruitment practices in the Australian law school

\footnotetext{
${ }^{17}$ In total 63 part-time students and 120 full-time students participated in Sommerlad's study. Each student completed two questionnaires: one at the beginning of their course and one at the end of the course. Sommerlad followed up the first questionnaire with focus groups that around one-third of the students participated in. The focus groups were then followed up by semi-structured interviews with the students, largely drawn from the full-time students, with some part-time students participating. Selected members of the cohort were later interviewed at staged interviews during their training contract and into their first year two years of legal practice post-qualification, see Sommerlad 2007, p. 196.

${ }^{18}$ Interestingly, some of the ANU LLB students in our research expressed concern about the impression that because the ANU's law program has a predominant international law focus, their counterparts at commercially-oriented law schools in universities in Sydney and Melbourne will have greater opportunities for career paths in large commercial firms.

${ }^{19}$ For example, Sommerlad noted that LPC students' cultural capital includes their secondary school grades, their school attended, and sporting abilities, see Sommerlad 2007, p. 205.

${ }^{20}$ Jewel's essay consistently uses the term "corporate law" without any reference to "commercial law", even though corporate law is a subset of commercial law.
} 
field. We also present the voices of the undergraduate and PLT students in the Australian law school environment, and of early career commercial lawyers who were only a few years earlier actors in that social space.

\section{PART III: METHODOLOGY AND LIMITATIONS}

"Though this be madness, yet there is method in't." William Shakespeare, Hamlet

\subsection{RECRUITMENT}

We decided to recruit law students enrolled at ANU to minimise any proximity issues, as our school is part of the ANU College of Law, where we teach in its PLT program. ANU is located in Australia's capital city, Canberra. The ANU College of Law has around 1,400 students, many of who study for their LLB or JD degree, with the PLT course delivered online to students across Australia and internationally. ANU is ranked in the top 50 globally, and number one in Australia, in the QS World University Rankings. We decided to recruit undergraduate students who had completed two of the core compulsory subjects: Corporations Law and Lawyers, Justice and Ethics. This ensured students volunteering for the research were more informed about commercial law and ethics. Similarly, we also decided to recruit PLT students who had already completed the core compulsory subjects Commercial Practice and Legal Ethics in the PLT program. ${ }^{21}$ Whilst there is no official designation of an early career lawyer, we decided that early career commercial lawyers eligible to volunteer for the project would have experience in commercial practice of up to five years. Again, due to proximity and convenience considerations, we decided to recruit commercial lawyers from the Canberra legal community of which approximately 2,400 lawyers practice in private firms, government agencies and community legal centres, along with some as in-house counsels or sole practitioners.

Volunteers in the research were recruited in various stages from June 2014 to September 2015 via social media and email. Originally, we sought a minimum of four volunteers for each focus group, but due to the challenges of recruitment, we slightly relaxed the pre-requisite requirements: one of the undergraduate students was from the University of Canberra, ${ }^{22}$ and one of the lawyers had seven years commercial practice experience. The principal researcher moderated six focus groups (two focus groups for each of the three categories of volunteers) in the second half of 2014, with each comprising between four and six volunteers. An assistant moderator was also present. Focus group sessions were held at the ANU College of Law. Due to the inability of some prospective volunteers to participate in the focus groups, we expanded the project by organizing semi-structured interviews with individual volunteers, giving us more flexibility to widen the circle of volunteers with an individual perspective. Twenty-four semi-structured interviews were conducted with seven undergraduate students, eight PLT students, and nine early career commercial lawyers over two periods: between July and December 2014, and between July and September 2015. All interviews were conducted in person at the ANU College of Law or by telephone/Skype. Each volunteer received a $\$ 25$ Co-op Bookshop voucher for their participation.

\subsection{DATA COLLECTION}

Focus group sessions ran between ninety minutes and two hours, with interviews running between thirty to forty five minutes. Volunteers were asked a set of pre-determined questions to stimulate discussion and follow-up exploratory questions in the focus groups and interviews. Volunteers were questioned about their experience of studying ethics at law school and the role of legal ethics in law studies or commercial legal practice. We explored the volunteers' impressions of commercial law, with the lawyer volunteers asked to compare their impressions as students with their current attitudes. Volunteers were asked which subjects they preferred studying in their law studies; students were asked which areas of law they were interested in practising, and lawyers were asked how their law studies prepared them to be a commercial lawyer. After the initial reading of the focus group transcripts, it became apparent that wellbeing and work-life balance emerged as key themes requiring further investigation. As a result, we included questions about wellbeing and work-life balance in interviews conducted between July-September 2015. This led the principal researcher to email follow-up questions to

\footnotetext{
${ }^{21}$ To avoid any potential conflict of interest during the principal researcher's teaching of Commercial Practice in the PLT program, PLT student volunteers were recruited by a school administrative officer rather than the principal researcher directly. The officer revealed the names of the PLT volunteers only after their Commercial Practice grades were released.

${ }^{22}$ The University of Canberra's law school was established in 1993.
} 
volunteers who participated in focus groups or interviews in 2014 , with a written response rate of about $50 \% .{ }^{23}$ All focus groups and interviews were audio-recorded and transcribed verbatim by the principal researcher. We reread and re-analyzed the transcripts and follow-up written responses to identify elements to categorise into themes and connections, and develop a consensus-based coding scheme for data interpretation (Harding 2013, Litosseliti 2003). The principal researcher used the scissor-andsort method to code phrases, sentences, and participant exchanges relevant to the categorical themes, as part of the qualitative analysis that occurred over several months to allow immersion and familiarity with the transcripts.

\subsection{LIMITATIONS}

The research has some limitations. The research would have benefited from more background data of the student participants, such as whether they were the first in their family to study law and their secondary school backgrounds. However, this was beyond the scope of the research, although such data could have provided further context to the findings. We also do not claim that the law students (all but one were students at ANU) in our research are a representative sample of law students in universities around Australia. Yet, we submit that the data which emerged from the sample provides insights and themes that are relevant and should resonate with law student counterparts in other Australian universities. As flagged in the literature review, the SES results in some universities located in two of Australia's largest metropolitan areas (Sydney and Melbourne), are relatable to our research with respect to information from careers advisors. The literature review also highlights some contributions to a 2020 collection of scholarly literature focusing on wellness in law (Marychurch and Sifris 2020), providing a more contemporary relationship to our research data especially in relation to students being informed of career paths beyond law school.

We were able to obtain from the participant lawyers details of where they studied their LLB. This provided diverse insights which we could compare with the law student participants. Six of the participant lawyers were
ANU law alumni, and three were law graduates of the University of Canberra. Three were alumni from law schools in Sydney, the most populous city in Australia: the University of Sydney ( $n=1)$, University of Technology Sydney $(\mathrm{n}=1)$ and Macquarie University $(\mathrm{n}=1)$. Another was a law alumna of the University of Tasmania (whose law school was established at the end of the $19^{\text {th }}$ century), one was a law graduate of Bond University (to date the first and only private university in Australia to offer a law degree), and one was an alumna of the law school of New Zealand's largest university, the University of Auckland.

We acknowledge the participant lawyers, all of whom practice in Canberra are not representative of the legal profession Australia-wide. As Canberra is the seat of national government, it has the highest proportion of government lawyers (46\%) compared with the nationwide figure (12\%) (Law Society of New South Wales 2018, pp. 22-23). This closely reflected the percentage of government lawyers ( $n=8,42 \%$ ) who comprised the lawyers in the research. An unintentional counterbalance was that more private practitioners volunteered for the semi-structured interviews than the focus groups, ${ }^{24}$ thus being more reflective, and even slightly over-representative, of the Australiawide composition: $69 \%$ of lawyers Australia-wide are in private practice, $77 \%$ of lawyers $(n=7)$ volunteering for interviews were private practitioners. Females constitute $61 \%$ of lawyers (across all practice areas) nationwide who have practised for up to five years after admission (Law Society of New South Wales 2018, p. 20). In comparison females comprised $89 \%$ of the lawyers volunteering for the research. Both the lawyer focus groups were all-female $(n=4, n=6)$, and only two male lawyers volunteered for the semi-structured interviews (compared to seven females). There was no apparent explanation for the large disparity between female and male lawyer volunteers, but this may explain the dominant themes of work-life balance arising from the lawyer focus groups and interviews. ${ }^{25}$ Amongst the undergraduate and PLT students volunteering, females $(\mathrm{n}=20)$ outnumbered males $(\mathrm{n}$ = 13). This is consistent with 2017 national estimates which showed females comprising of around two-thirds of law graduates (Hart 2017). ${ }^{26}$ Again, the prevalence of

\footnotetext{
${ }^{23}$ These follow-up questions sought volunteers'responses to wellbeing, work-life balance and further insights about impressions of commercial law and the role of ethics.

${ }^{24}$ One of the lawyer focus groups comprised two government lawyers and two private lawyers, the other comprised four government lawyers and two private lawyers. Two government lawyers and seven private lawyers volunteered for interviews.

${ }^{25}$ At the end of an all-female undergraduate student focus group, one of the volunteers offered an explanation to the moderator on the paucity of male student volunteers, "You appeal to our emotions when you send the email, like could you help us", eliciting laughter from the fellow volunteers.

${ }^{26}$ The growth was measured from 2011 to 2016, see Law Society of New South Wales 2016, p. 4.
} 
work-life balance issues arising amongst the students was probably reflective of the higher number of female volunteers (one of the undergraduate law focus groups was all female $(\mathrm{n}=5))$.

Another limitation was the potential of selection bias arising from the challenges of recruiting the minimum number of volunteers for focus groups and interviews. We deemed necessary a minimum of four volunteers per focus group, and a minimum of five volunteers in each participant category of interviews. Difficulty recruiting undergraduate law students and early career commercial lawyers was acute, leading to the principal researcher reaching out to colleagues in the ANU College of Law and the Canberra legal community to extend invitations to students and lawyers in their networks. The risk related to a skewing of the data. However, the challenges of recruiting, especially for focus groups, is cross-disciplinary (MacDougall and Fudge 2001, p. 120; Dyas 2009, pp. 65-66).

\section{PART IV: DATA ANALYSIS}

"All the world's a stage, and all the men and women merely players.

They have their exits and their entrances." William Shakespeare, As You Like It

As legal educators who teach PLT students as they approach admission to practice, this study of the Australian law school environment is timely. We seek to understand how the information gap exists in that space, and its impact on students, some of whom are still discerning their career path. Our analysis seeks meaning and context in the volunteers' responses by applying Bourdieu's tools, appreciating that whilst a volunteer's responses could be snapshots not necessarily representing their whole experience, they provide the basis to research the information gap. All volunteers referred to in this article have been allocated identifiers: the undergraduate law students are identified "U1", "U2", and so on, the PLT students are identified "P1", "P2", and so on, and the early career commercial lawyers are identified "L1", "L2", and so on.

\subsection{DOMINANCE AND DISPOSITION: THE LAW SCHOOL SPACE AND STUDENT HEADSPACE}

A strong consensus emerged amongst the volunteer early career commercial lawyers about their reflections of the dominance of top-tier firms in their law school space, representing the Bourdieusian cultural field composed of competing positions (Dezalay and Madsen 2012, p. 441). In one of the focus groups, three of the lawyers, in response to the moderator's question about their exposure to law careers marketing in their law student days, all reflected on their concern about the pervasiveness of top-tier firms. L2, a lawyer in mid-tier private practice, opened the narrative by recalling:

We had a lot at the law student's society, they'd often have seminar series where the firms would come and speak...most of them were top tier, mid-tier firms...they rarely get a non-commercial firm.

L3, another lawyer in mid-tier private practice, agreed with L2. This led the moderator to ask L3 about her exposure to marketing in law school:

We just had essentially nights dedicated to the clerkship programs and so it was just commercial, just top tier...there was nothing below that...you might be told "There are lots of options out there" but there was never any nights spinning the benefits of working in a mid-tier or a boutique firm.

L4, a government lawyer, confirmed this was her experience in law school. L3 continued, "We never had nights that were about working for government or NGOs or anything like that." L2 added the coda, "or even working with a law degree as a non-lawyer", driving home the point about the dominance of large commercial firms in their law school space.

In another focus group, L8, a government practice lawyer, noted that her impressions of the law and lawyers:

started early in university where major law firms pitched to you about how great their careers are and they're all commercial law firms pretty much...[where] you earn big money, and also only in commercial law.

L8 continued by highlighting the lack of broader opportunities:

You never had any family law firms come out to pitch the universities...it was five or six of them just got back to university and tell you how great commercial law was.

When the moderator asked the lawyers if they could recall criminal, family or wills firms attending at their law school, several said they could not remember such occurrences. 
L8's reference to "five or six" of them was a reference to the "Big Six" - the six top-tier firms in Australia. ${ }^{27}$ L8 later in the focus group used the term Bix Six, as did other volunteers. U13 used this phrase in her interview. U9 used a similar variations in her focus group ("the Top 6 in Sydney"). L12, a lawyer in a global firm, reflected on his clerkship applications to "all the top six" (he also recalled the careers fair hall "packed out" with "commercial law and the big firms"). When the volunteers were asked to provide their impressions of "commercial law" and "commercial lawyers", some of the descriptors epitomised the power and influence of top-tier firms.

$\mathrm{U} 1$, in his follow-up written response, thought of "big firms...trying their best to earn more money", P1 in her focus group had a similar response with "big firms, big business", and P14 in her interview thought "big companies...lots of money." U15, who had experience working in a mid-tier firm, responded in his interview, "big top tier law firms, big deals, the multinational deals, big corporate mergers." In a similar vein, P7 (who worked in a global law firm) thought "companies, company transactions, company disputes, big agreements". Volunteers' perceptions were void of any references to small or even medium-tier firms or small businesses. Some volunteers admitted these impressions were not necessarily grounded in reality. However, the powerful repetition of these terms goes to highlighting the impact of top-tier firms dominating the law school space, and in shaping the disposition in the student body psyche. Students' perceptions about commercial law and the ideal commercial lawyer had a "big" and powerful thread: big firms, big business, big deals, big agreements, big money. Top-tier firms are so big, and their presence in the law school space - the cultural field - is so visible that they have the power to exercise dominance and hegemony. It almost becomes inevitable that many medium-tier commercial firms, government practices, and virtually all family, criminal and general practice firms do not generally enter the consciousness or lexicon of students in the same way the Big Six do. We argue that this vacuum contributes to the information gap to the detriment of students who desire information about a broader range of career options. Big impressions have the power to foment narrow perceptions of real law.
The experiences of the student participants went some way to confirming the information gap the participant lawyers experienced in their student days. U1 in his focus group observed that "mostly the bigger firms...with some medium firms" were present at careers fairs. P4 in her focus group commented that the careers fairs comprised "all the big firms." U5 in her focus group lamented that:

it's a shame that there's not much more representation of the lot of mid-tier firms in Canberra...they're considered very good, good law firms in Canberra and I've been exposed to them through my work. But it would be nice to see them on campus as well because the majority of students, that's where we'll be going.

U5's perceptions about the aspirations of her fellow students were heightened by her experience as a former member of the LSS executive. U5 understood, through her LSS role, how sponsorship buys visibility (Manderson and Turner 2007, p. 656). U5 pointedly observed that on the LSS executive "there's a certain type of person" aiming for a top-tier job "so they assume everyone else is as well." This might explain why the LSS did not encourage smaller firms to come and recruit students at ANU. U7 commended U5 on her point about the responsibility the LSS has on firms' presence in the competitive law school space, but suggested that despite "everyone seeming to be aiming for these top-tier firms in Sydney", there isn't that "broader understanding that you know there may be similar opportunities elsewhere." U9 sympathetically responded by indicating it was an issue she tried to raise when she herself was an LSS executive member. U9 commented that the LSS sells premium sponsorship for five figures in return for naming rights and the right to sell "clerkship spots" at the LSS "career event of the year". The high cost of premium sponsorships rules out most smaller firms from being able to pay to play the game. Such was the influence of sponsorship on U9 that it impacted on her perceptions of the legal profession. U9 recalled that in her first two years of law school the only law firms she could name were the ones that "spent money through the LSS" or saw "their name up, all their signs around". As an LSS executive member, U9 attended a clerkship evening in her second year where she was:

\footnotetext{
${ }^{27}$ Collectively, Australian top tier firms are informally the "Big Six" (equivalent to the UK's "Magic Circle"). Whilst legal profession opinion varies about the number of top tier firms particularly with global mergers or associations, the general consensus is there are six based on their number of employees and offices, international links, and clients' size and profile, see Pinnington and Gray 2007, p. 154.
} 
like being a body in the crowd...I heard from all the firms, you know I was like well all right so those are the firms I can work for. It was only once I got further along I learned of opportunities outside that.

The observations of U9 warrant further research into the activities of law student societies, particularly their sponsorship by law firms and the influence on the distribution of career information to students.

Power is never absent from a social field (Manderson and Turner 2007, p. 651), and our research highlights that in the ANU law school space, top-tier firms have the power, economic capital (sponsorship funding) and social capital (their collaboration with the LSS) to exercise a gravitational pull on student crowds. The psychology of crowds or mobs is beyond the scope of this article, but the information gap is perpetuated by the truism that crowds begat crowds, where the fear of missing out permeates as an emotional contagion. This ideal of legal career success is reinforced (or even influenced) by some LSS leaders who transpose their own top-tier ambitions by pursuing lucrative sponsorships that are out of the reach of all but well-moneyed firms and some government departments. Apparent from the research is that many students are drawn to the power and prestige exuded by top-tier firms in their marketing events (pop culture depictions of smart-suited lawyers is also influential, but that is for another article). Subconsciously, these students find that their "taste of real law" (Manderson and Turner 2007, p. 663) perpetuates "big" (yet paradoxically, at the same time narrow and possibly unrealistic) impressions of commercial law and commercial lawyers.

This leaves little room in the law school space and in the consciousness of students for law firms lacking the power and capital to be effective actors in the law school environment. The crowd can pressure some students, who may have successful careers as commercial lawyers in smaller firms or government, or as family or criminal practitioners, to question and re-align their values in pursuit of the capital that being a top-tier lawyer purportedly bestows. Much of the crowd's embrace of top-tier firms also has the insidious effect of crystalizing the information gap for fellow students who have no interest in a career with the Big Six. U8, who was in the focus group with U5, U7 and U9, expressed concern that her admitted lack of motivation to attend LSS events, careers fairs or clerkship evenings could limit her ability to discover "the kind of jobs that I can get." U9 empathically proposed that there is scope for the ANU careers centre to be more proactive, rather than leaving it up to the LSS who are student volunteers, but unfortunately for many students there "is a big information gap".

\subsection{CULTURAL CAPITAL AND HABITUS: BODIES IN THE CROWD}

Whilst the dominance of top-tier firms in the law school space provides much context for information gap, we seek to avoid utilising Bourdieu's tool of cultural field dominance as a standalone concept. Similarly, we deploy Bourdieu's habitus - "the feel for the game" (Bourdieu 1991, p. 13) - in combination with the field (Dezalay and Madsen 2012, p. 442). Bourdieu's habitus is a scheme of production of practices, and also a system of perception and appreciation of these practices (Bourdieu 1991). We benefited from some volunteers who recounted their observations of students adopting the habitus generated by top tier dominance in the field, and its impact on the wellbeing on students who lacked the capital to obtain a coveted clerkship - the ace in Bourdieu's competitive game of cards.

Ingrained in law students seeking top tier jobs is the understanding that the application process is, as U1 described in his focus group, "fairly competitive". L3 was more straightforward by recalling that the top tier firm's marketing efforts were like "shock and awe campaigns", where students were "just spammed" with pitches from top tier firms proclaiming their benefits, further entrenching the competitive atmosphere. L2 reflected with dismay that a lot of her fellow students "were just straight commercial, like those were the only jobs that they ever applied for, they wouldn't consider anything else." L2 thought this limited their career options, with their perception that working in a top-tier or mid-tier firm was the "pinnacle at the end of their study." U5 drew much laughter from her fellow volunteers when she made a revealing observation that the sort of people who have volunteered for the focus group are "probably a different type of law student to the ones who....are probably doing a clutch of [clerkship] applications right now because they're due soon." A fellow volunteer intoned "hush" to further laughter from the group. This candid exchange pointed to the open secret that applying for clerkships is so competitive that aspiring law students will put virtually everything aside to prepare their application. L3 recalled knowing students "who essentially stopped going to uni, and stopped studying for a month, and instead dedicated that month to clerkship [applications]." L2 followed with 
her observations, "It was clerkship month and then that's what they did instead of going to uni."

Whilst none of the volunteers indicated that any top tier firms encouraged students to suspend their studies for a month to submit their clerkship applications, it is no surprise to hear some students went to these lengths to demonstrate they have the capital (willingness to work long hours by putting the firm first) to qualify as a toptier lawyer. One consistent thread across all the volunteer categories was the impression about the very long hours expected of commercial lawyers:

“12, 13, 14 hour days, weekends" (U9 in focus group)

"15 hours in a day" (L7 in focus group)

"15 hours day" (U14 in interview)

"16 hours a day, 16 hour days" (P6 and P8 respectively in the same focus group)

"90 hour weeks at the big firms" (U16 in interview)

"work you around the clock" (U10 in interview)

"working very long hours" (U14 in interview)

"start early in the morning, finish late at night, go in on weekends" (P13 in interview)

"work up to 10/11pm" (L10 in follow-up written response)

"there until 11, 11.30 at night and coming in very early the next day because of the expectations" (U13 in interview)

These impressions were confirmed by two of the lawyers (who worked in top-tier firms):

"working past 10 o'clock, in some situations I was working past kind of 4 o'clock in the morning" (L17 in interview)

"we worked 40 hours straight" (L12 in interview)

Long hours are more power could be inferred from these impressions and experiences. As discussed earlier in this article, perceptions of commercial law itself predominantly relate to big firms. The mantra of long hours may be ingrained in the habitus of some students who decide a month off from their law studies is a small price to pay to demonstrate their ability to put the top-tier firm first. If it means adopting the habitus of a real-life toptier lawyer by devoting 16 hour days on their clerkship application, then so be it.

Another way the information gap is further perpetuated in favour of top-tier firms is the absence of a habitus generated by other firms. L3 recalled that the only other time she was aware of other options was at the careers fair where she encountered a booth for government departments. L3 bemoaned the lack of engagement with the government representatives ("asked a couple of questions and take a brochure") compared with that of the top tier firms. L3 recounted that the government representatives would:

essentially deliver you the rote learned like answers,

"It's a great place to work, you know", "We do this kind of stuff" but you don't ever sort of get a feel for it.

Given the large number of law students seeking future employment, it is possible government departments may attract enough sufficiently qualified applicants without having to outlay the capital to match the top-tier firms. Perhaps government departments (and medium and smaller private firms) know they do not need to play by the same recruitment rules that top tier firms impose on their applicants. However, L3's experience highlights the challenges of chipping away at the ingrained habitus (Jewel 2008 , p. 1223) amongst law students who are drawn to top-tier firms without the knowledge of broader career options. The information gap is not just about the lack of information in the law school space but also concerns the lack of awareness concerning diversity of career paths. It also pertains to the wide gulf created by the high octane enthusiasm displayed by the top-tier firms compared with the less vigorous approach by the rest of the legal profession that contributes to the domination of top-tier firms in the activities and minds of many students.

\subsection{FAR FROM THE MADDING CROWD: COMPLICITY AND RESISTANCE}

Dezalay and Madsen observed that in the social space the structural centre of gravity is where the effects of the field are more strongly felt, while the effects eventually diminish at the outskirts (Dezalay and Madsen 2012, p. 441). Yet it is these outskirts where many students are positioned, and where the information gap is wide because of the lack of broader career opportunities presented to students on the edges of this space. It appears a large number of students in the research were on these outskirts (by choice or otherwise), as they did not indicate they actively participated in their law school's careers fairs that were dominated by top-tier firms. For example, in one of the PLT student focus groups, the volunteers were tepid about embracing the careers fairs due to lack of interest or the predominance of top tier firms. U5's earlier observation about the type of volunteers who were drawn to this 
research possibly explains their disposition to broader career perspectives or their askance at, or antagonism towards, top tier firms. L2 mentioned in her focus group that it was "a bit offensive" how "impressionable" the firms thought students were, and in the other lawyer focus group, L5 cynically associated the firms' distribution of promotional items at careers days with their message "oh gosh, great to work there." However L12, a global firm lawyer, recounted his excitement at gravitating to the "more cool" and "impressive" things like the notepads and the USB sticks. L12 noted the top tier firms had the money on this branding and advertising, and he wanted "to be a part of that."

Some readers may interpret L12's pull to branded stationery and trinkets as being the superficial product of the promotional abilities of top-tier firms. However, he, along with two students who aspired to practice in top-tier firms, displayed a sense of realism and passion about commercial practice that transcended notions of wealth and dominance exuded at the centre of gravity in the social space. L12's advice to law students thinking of working in a large commercial firm was:

I wouldn't recommend doing this sort of work for the lifestyle or the money. You do have to really love it. You have to be passionate about contracts.

U11 indicated his focus at university had been "very much commercial courses" and he "loved" equity and trusts and restitution. U13 expressed frustration about some students who attempted to leverage Bourdieu's habitus and play the top-tier game which they were apparently ill-fitted for:

The thing I cannot understand right, and it frustrates me beyond belief is the people who go to law school and they say, "I want to work for a top tier commercial firm" and you ask them why, and they say, oh because they'll earn lots of money. And I say why don't you just do a commerce degree, out in three years you know, and you'll earn heaps more, and there's no graduate glut in finance and accounting, in fact it's a skill shortage area you know. And they still go, oh, but I can't do maths you know, and I say well you know, at the end of the day you're going to have to do maths if you want to work in commercial law anyway, you know what's the end game here? And then you find out their favourite subject is criminal law, you know and you say, well, you know, honestly and truly. It comes down to status and ego.
Money and prestige could also have been underlying motivators for L12, U11 and U13 in their quest for a corporate career. However, U13's insightful commentary speaks to the larger question of which actors in the cultural field (in addition to the top-tier firms and the LSS) are also complicit in the emergence and strengthening of the information gap. The criminal law enthusiasts that U13 pointedly refers to have every right to adopt the habitus by gravitating to top-tier firms. Perhaps students who are initially averse to commercial law may find their true calling and practice commercial law, or more specifically become corporate lawyers. Their motivation to practice with large commercial firms may be largely driven by the habitus generated by top-tier firms. However, we submit that students identified by U13 are complicit actors (knowingly or not) in the development of the information gap at the expense of others who want to learn more about criminal law or family law careers. This complicity has the effect of artificially enlarging the crowd around top-tier recruiters. This might rankle students with a true passion for a top-tier commercial career, but it adds status, ego and prestige to top-tier firms. Top-tier firms are most influential in the law school environment if enough students adopt the dispositions to shape the habitus of the law school space. It can also have the underhanded effect of giving the LSS a crude and uninformed impression (by glancing at the masses of bodies in the crowd circling the top-tier recruiters or relying on potentially biased feedback from top tier recruiters) that more students are drawn to, and excited by, top-tier marketing activities. This could provide the LSS with less incentive to devote adequate resources to informing students about the broader range of career options, further solidifying the information gap and perceptions of real law.

Despite the mass of excitement generated by the domination of top-tier firms, in the law school space, one of the volunteers displayed an unequivocal and a principled resistance to the habitus. P1 stated in his focus group that he wasn't influenced by the top tier firms, and was proud not to be "a victim of the siren's call" to come climb on top of other graduates and then the corporate ladder to "partnership of the bigger law firm." P1 was already confident of his career path as a barrister. P4, just before expressing concern about her lack of awareness of the clerkship process, concurred with P1's resistance. 


\section{PART V: IMPACT OF THE INFORMATION GAP}

\author{
"Something is rotten in the state of Denmark." \\ William Shakespeare, Hamlet
}

\subsection{SYMBOLIC VIOLENCE: TAKING THE NEXT DROP}

A revealing and poignant dialogue between $\mathrm{L} 1$ and $\mathrm{L} 4$ (both lawyers in the same government agency) in their focus group drew attention to the lingering effect of the law school information gap:

L4: "There's only so many roles that top tier - "

L1: "Top tier, exactly."

L4: "And you don't want to feel like, if you don't get that -"

L1: "Yes.'

L4: "That you somehow haven't - "

L1: "Had to take the next drop."

L4: "Somehow it's a compromised position or, or you're not, that you failed."

Moderator: “Failed because you couldn't get a job in a top tier firm?"

L4: "Yes."

This very candid exchange illuminated the struggles and insecurities arising from a perception that non top-tier commercial law careers are a counterfeit when compared to the careers of their top-tier counterparts and maybe some in the legal community at large. L1 and L4 did not suggest aspiring to a top-tier career, but they were resigned to a belief that a non-top-tier career represented a failure to become "real lawyers". Through the Bourdieusian lens, their submission to the top-tier notion of success confirmed their complicity as victims of Bourdieu's "symbolic violence" of the dominant (Bourdieu and Wacquant 1992, p. 167). Dominance becomes a "means of reproducing an exclusionary identity" (Francis and Sommerlad 2009, p. 79). This results in L1 and L4 perceiving their oppression (for example, inferior feelings about their law jobs) as the "natural order of things" (Webb et al 2002, p. 25). It is unclear if L1 and L4 became subject to symbolic violence during their time in the law school space or after their graduation to enter legal practice. We submit that the information gap pushes a dominant and aspirational message, permeating through the law school space, that being selected by a top-tier firm bestows on a student elite status. Select students, who demonstrate a feel for the game, are deemed to be at the top of the game in the competitive law school space. Anything less means the metaphorical drop downstairs that L1 and L4 felt was inflicted on them. "Top tier", "next drop" - these are examples of the lexicon entrenching symbolic power of the dominant in the law school space, and forming part of the language of the habitus.

\subsection{LANGUAGE AND SYMBOLIC POWER: UPSTAIRS, DOWNSTAIRS}

A top-tier law firm can confidently assert there is no information gap in the law school space because students are provided with a copious amount of information about top-tier careers. From the top-tier perspective, this assertion is accurate. Through the Bourdieusian framework, what the top-tier firms say and how they say it, reveals to an extent their position within and outside the field (Dezalay and Madsen 2012, p. 448). It also highlights a symbolic struggle to inculcate a particular world view on others (Webb et al. 2002, pp. 95-98). Bourdieu wrote that language itself is an expression of the state of relations of symbolic power (Bourdieu 1989, p. 20). Language is not in itself powerful, but it assumes symbolic power when it is "used in particular ways, or by particular groups and institutions" (Webb et al. 2002, pp. 95-98). We posit that the language used by students and lawyers to describe large law firms reproduces symbolic power of top-tier firms and marginalises most of the other firms. This further buttresses the information gap at the expense of students who despair about the void of information concerning other career paths. The use of language is so ingrained that even students and lawyers who oppose top-tier domination in the law school space are unaware their casual use of these terms reinforces the domination at their expense.

Acclaimed American linguist Samuel Hayakawa wrote:

A word generally has meaning in relation to its opposite; you need to have "rich people" in order for "poor people" to mean anything (Hayakawa and Hayakawa 1992, p. 123).

For Hayakawa, inferences are important and judgment is implied in language (Hakayawa and Hayawaka, 1992, pp. 25, 29). The term "top-tier firm" was one of the most common terms expressed by the research volunteers. Six undergraduate law students, three PLT students, and ten lawyers used the term "top-tier firm" or its slight variation "top-tier commercial". Of these, only two of the 
undergraduates had completed a clerkship with a top-tier firm, none of the PLT students had clerkship experience, and only three of the lawyers worked in top-tier firms. It is also interesting to note that clerkship was formerly a generic term under the superseded articles system of legal training in Australia. The term clerkship has now been appropriated exclusively to represent a position that is unique to the top tier firms. The implication of "top-tier" is that the rest of the firms are not the best firms with all the connotations arising. This creates the impression of a sport league ladder (Bourdieu was known to write about sports (Clement 1995, p. 147), and his tools of "field" and "feel for the game" conjure up sporting metaphors). In this ladder top-tier firms have top clients, top working conditions, top prestige, and top opportunities. Any firm below the top are of lesser-value, less prestigious or even second-rate. To put it frankly, a more sinister implication is that firms that are not "top-tier" will never be at the top of the table. Whilst Google Scholar ${ }^{28}$ may not be an accurate reflection of the hierarchical language in the legal community, at one level it highlights the clear dominance of top-tier firms in shaping the linguistics of law students. A search of "top-tier firm" brings over 600 results compared with nine for "large-tier firm", and one for "big-tier firms". ${ }^{29}$ The caveat to these searches is that a "top-tier firm" could include accounting or other professional firms. Nevertheless the massive gulf between the search numbers highlights the influence and power of the top-tier firm nomenclature across several levels.

The notion of top-tier firms being at the top is augmented by some volunteers in their perspectives (and even criticisms) of top-tier firms. U5 in her focus group believed that experiencing the world of commercial law was an opportunity to "skill-up". U14 in her interview expressed conflict on whether to pursue a career with a "big law firm" where she would be "at the top of my game" and "do all the big cases" or whether she would be happier in a mid-tier firm. L3, in criticising the predominance of top-tier firms at careers fairs, noted the absence of firms "below" the top-tier. As previously mentioned, L1 and L4 referred to their government law experience as being the "next drop" from top-tier practice. U11 reinforced the "Upstairs, Downstairs" ${ }^{30}$ perception of the legal hierarchy when he recounted being told at a clerkship interview that the benefit of choosing a top-tier firm is "it's easier to go from top tier to lower-tier" but it's harder to do the reverse, akin to the "analogy of how you can't ski uphill" (further supplementing Bourdieu's sporting metaphors). One implication of this is that top-tier graduates are eagerly sought after by the rest of the legal community (maybe there is some truth to that) who desire to recruit top-tier capital into their ranks, with the endowed firm proudly rising slightly higher in the sports table (but never enough to reach top-tier level of course). An elitist perspective is that the only members of the top-tier club are those with the fortune of commencing their careers in top-tier firms. A demeaning interpretation is that anyone starting their legal career on any other rung of the ladder (that is anywhere below the top rung of the top-tier firms) will be pitied in their aspirational struggle to reach upstairs and join the exclusive ranks of top-tier life.

We are not suggesting that the linguistic usage of "toptier firms" be curtailed in the law school space. This would be unrealistically extreme and will most likely offend the principles of free speech. In fact, we consistently use the descriptor "top-tier firm" in this article and in our communications with law students in the teaching sphere. However, it is important for the law student community, including law teachers, to recognise the underlying meaning and impact of the terminology they employ, even if it is utilised to critique the domination of top-tier firms.

\section{PART VI: BROADENING CAREER INFORMATION TO LAW STUDENTS}

\author{
"To sleep, perchance to dream." \\ William Shakespeare, Hamlet
}

\section{1 “I WISH THAT I KNEW WHAT I KNOW NOW, WHEN I WAS YOUNGER." 31}

The moderator asked the lawyers in the focus groups if there was anything they wish they had known before they became commercial lawyers. In one focus group, the responses of L5 and L8 emphasised the mindset when they graduated, strongly influenced by the dominance

\footnotetext{
${ }^{28}$ A search engine for scholarly literature and academic publications.

${ }^{29}$ Google Scholar search conducted on 3 June 2020.

${ }^{30}$ British TV drama Upstairs, Downstairs (1971-1975) portrayed a townhouse where the servants represented the "downstairs", and the family (their employers) residing "upstairs" symbolised the upper class.

${ }^{31}$ Ooh La La, Performed by The Faces (1973).
} 
pushed by top-tier firms in their erstwhile law school space. L8 responded:

I thought being a successful commercial lawyer meant working in one of the big six firms and now I kind of realise that's definitely not the case listening to a lot of my friend's experiences, people I work with. There's a lot more to commercial law than working in one of those places.

\section{L5 concurred:}

I certainly came out of law school thinking that going into the big top firms was the best option you could go for, best thing you could do. Now having been out in practice and I realise it's not really that cracked up to what it appears to be when you're a student.

These reflections capped off the concerns expressed by some of the volunteer students. It confirms an environment where the ongoing dominance of top-tier firms and their representation (or misrepresentation) of real law can narrow career horizons quickly and drastically (Pryor 2008, p. 49). U5 in her focus group highlighted the importance of being ambitious, but it was a shame that 'realistically there are so many options for graduates not exposed to them on campus.' L9, in the same focus group as L5 and L8, was one of the strongest proponents of bridging the information gap by encouraging the entrance of a broader slate of firms into the law school space:

I definitely would have had more variety, rather than just the top tier commercial firms come to us. Let's focus on mid-tier, let's try to get some boutiques, let's try get some criminal, let's also try to get...government departments.

L9's advocating a wider range of actors, in the cultural field, is especially pronounced given she had practised as a lawyer in two top-tier firms.

\section{2 "ALWAYS BE A FIRST-RATE VERSION OF YOURSELF, INSTEAD OF A SECOND-RATE VERSION OF SOMEBODY ELSE." 32}

We strongly concur with the volunteers that bridging the information gap in the law school space is essential to give law students greater cognisance of career choice and to achieve their dreams. One option is to adopt a recommendation of ANU's own LSS Law School Reform Committee that:
Mentors from a range of fields outside the academy and mainstream corporate law firms should play a much more active role in the law school, with a particular focus on raising the aspirations of later year students and showcasing the opportunities available to them (ANU LSS Law School Reform Committee 2010, p. 59).

The full impact of the information gap on the wellbeing of students is beyond the ambit of this article. ${ }^{33}$ Yet it is relevant to students who encounter anxiety, depression or stress in the law school space. U5 in her focus group was critical that the law school failed to take steps later in the law degree when it becomes necessary to:

alleviate those problems of competitiveness or depression...especially for example in fifth year when things are getting really, you know, tough for students.

While a variety of factors can affect a law student's wellbeing which are unrelated to their studies or prospects of employment, a survey into the wellbeing and law school experience of students at the University of Melbourne found that:

The broad message was that students were stressed about their employment prospects and many would welcome more proactive counselling about opportunities "in and out of law" (Larcombe et al 2013, p. 426).

However, if we were to take a more cynical approach, we submit the introduction alone of new actors in the field (for example, government or community legal service providers) to impart information to students about broader career options, may lack the desired initial impact due to the ingrained habitus amongst the crowd influenced (or enthralled) by top-tier dominance. Bourdieusian social theory tends to assume the "habitus will adapt or accommodate itself to the field", and the "habitus cannot alter the field because of the external, objective status that is attributed to the field" (Adkins 2003, p. 36). The power of top-tier firms manifests itself in the habitus to the point that by the time a student seeks other options such as a career in government, NGOs or other sectors, these choices are considered "alternative" (Pryor 2008, p. 49). The thought of an alternative career can be a "strange idea" (Manderson and Turner 2007, p. 665). As Hayakawa wrote, a word generally has meaning in relation to its opposite, and in the law school space the opposites to "alternative" 34 and "strange" just happen

\footnotetext{
${ }^{32}$ Quote by Judy Garland.

${ }^{33}$ We further address the link between the information gap and wellbeing, see Yau B., Catanzariti D., and Atkinson J. 2019.

${ }^{34}$ We are prepared to speculate that if the LSS were to promote top-tier jobs as "alternative careers", the top-tier firms may withdraw premium sponsorships.
} 
to be "top-tier" and "normal". The top-tier activity in the cultural field presents a powerful corporate image of real law which comes to have "normative currency" in the law school space (Turner and Manderson 2007, p. 786). Even U9 - who decried the domination of top-tier firms - later in her focus group derided the commercial section of a leading Australian government law firm because it was "regarded as a bit of joke" as "they're not making money for people."

Whilst top-tier firms dominate the law school space by reproducing their version of a model lawyer, it is not so simple for other actors to compete by replicating the actions of top-tier firms in the cultural field. Just as most shot-for-shot movie remakes are not as successful as the original, ${ }^{35}$ any attempt by alternative firms to operate "directly and aggressively on the home turf of the dominant" risks failing to gain traction (Pinnington and Gray 2007, p. 160). It may even appear embarrassingly awkward for these firms and the students they seek to attract, which could have the unintended effect of turning away prospective students. Rather, a new field within the law school environment needs to emerge with actors dedicated to question and redefine social hierarchy and power (Dezalay and Madsen 2012, p 443). For example, law teachers can influence students to have a broader vision of real law. In more contemporary literature on law student wellbeing, it is recommended that law teachers play a role in helping students "identify their goals in relation to legal works, or at least to clarify their values in relation to their career options." (Swannie 2020, p. 127). A bridge can be established for other firms to enter the law school space and assert their control and autonomy by establishing their perspectives and value of real law and real lawyers. This would give more students a broader and realistic understanding and choice of their career options in the legal community and beyond (Pinnington and Gray 2007, p. 164).

\section{PART VII: CONCLUSION}

\section{"If you build it, they will come." Field of Dreams}

The famous quote from the movie Field of Dreams is actually, "If you build it, he will come." However, it has been popularly re-interpreted over time to adopt an inclusive meaning. Ideally the law school field should be inclusive of the career aspirations - in and out of law - of all law students. Whilst top-tier firms have every right to establish themselves there, just as much as every other legal service provider, we cannot remain silent about the narrow flow of career information within the law school space that excludes the dreams of many students. We concur with Jewel's caution to law teachers that the danger of silence is the strengthening of the habitus which lends itself to reproducing existing inequalities amongst students in the law school field and the wider legal profession (Jewel 2008 , p. 1207). We value the importance of respecting the ability of students to make informed choices about their careers with a wider range of information at play in the field. That is not to disrespect their choice if they aim to be dealt the top-tier ace and pursue their notion of real law. Equally, a student's choice to seek a career in government, mid-tier, smaller private practice or other sectors must also be respected and valued as the practice of real law rather than an alternative. The observation of Professor George Williams, Dean of Law at the University of New South Wales align with our arguments. Professor Williams, who seeks to show his students the full range of career paths, commented in 2019 that law firms are "very good at dominating the landscape for law students" which can "create a narrow, linear path to a career" (Price 2019). Our article demonstrates that firms with substantial capital inevitably exercise the power to make their presence felt in law schools. With much at stake for students across Australian law schools, every effort is required to address and eventually eradicate the information gap and re-imagine this space to open the minds of students pursuing their dreams to become real lawyers.

\section{REFERENCES}

1. Adkins, L. 2003. "Reflexivity: Freedom or Habit of Gender?" Theory, Culture \& Society, 20 (6): 21-41.

2. Anheier, H., Gerhards J., and Romo F. 1995. "Forms of Capital and Social Structure in Cultural Fields: Examining Bourdieu's Social Topography." American Journal of Sociology, 100 (4): 859-903.

3. ANU LSS Law School Reform Committee 2010. "Breaking the Frozen Sea." (2010) https://www.anulss.com/ wp-content/uploads/2016/05/Breaking-the-FrozenSea-Report.pdf Accessed 4/3/19.

${ }^{35}$ The shot-for-shot remakes not as successful as the originals were Psycho, The Omen, and Funny Games, see Salt 2016, p. 467. 
4. Bourdieu, P. 1977. Outline of a Theory of Practice. Cambridge, UK: Cambridge University Press.

5. Bourdieu, P. 1984. "The Market of Symbolic Goods." In R. Johnson (ed.) The Field of Cultural Production: Essays on Art and Literature. New York, USA: Columbia University Press.

6. Bourdieu, P. 1989. "Social Space and Symbolic Power." Sociological Theory, 7 (1): 14-25.

7. Bourdieu, P. 1991. Language and Symbolic Power. Cambridge, UK: Polity Press.

8. Bourdieu, P. and Wacquant, L. 1992. An Invitation to Reflexive Sociology. Cambridge, UK: Polity Press.

9. Bourdieu, P. 2004. "The peasant and his body." Ethnography, 5 (4): 579-599.

10. Cook, A., Faulconbridge, J., and Muzio, D. 2012. “London's legal elite: recruitment through cultural capital and the reproduction of social exclusivity in City professional service fields." Environment and Planning A 44 (7): 1744-1762.

11. Clément, J. 1995. "Contributions of the Sociology of Pierre Bourdieu to the Sociology of Sport." Sociology of Sport Journal, 12(2): 147-157.

12. Dezalay, Y. and Garth, B. 1996. Dealing in virtue: International commercial arbitration and the construction of a transnational legal order. Chicago, USA: University of Chicago Press.

13. Dezalay, Y. and Garth, B. 2010. Asian legal revivals: Lawyers in the shadow of empire. Chicago: USA: University of Chicago Press.

14. Dezalay, Y. and Garth, B. 2016. "Lords of the dance' as double agents: elite actors in and around the legal field." Journal of Professions and Organization, 3(2): 188-206.

15. Dezalay, Y. and Madsen, M. 2012. "The Force of Law and Lawyers: Pierre Bourdieu and the Reflexive Sociology of Law." Annual Review of Law and Social Science, 8: 433-452.

16. Dyas, J., Apekey, T., Tilling, T., and Siriwardena, A. 2009. "Strategies for improving patient recruitment to focus groups in primary care: a case study reflective paper using an analytical framework." BMC Medical Research Methodology, 9(1): 65-74.

17. Evers, M., Olliffe, B., and Pettit, R. 2011. "Looking to the past to plan for the future: A decade of practical legal training." The Law Teacher, 45(1): 18-44.

18. Fisher, R. 2015. "The legal community's struggle with mental health.", 6 October, Law Report, Radio National. https://www.abc.net.au/radionational/programs/ lawreport/mental-health-in-law/6828762\#transcript Accessed 3/2/19
19. Francis. A. and Sommerlad, H. 2009. "Access to legal work experience and its role in the (re)production of legal professional identity." International Journal of the Legal Profession, 16(1): 63-86.

20. Harding, J. 2013. Qualitative data analysis from start to finish. London, UK: SAFE Publications.

21. Hart, C. 2017. "Law Council of Australia tackles gender bias with new workshops." Australian Broadcasting Corporation, Sydney, 17 February 2017. https://www.abc.net.au/ news/2017-02-17/law-council-of-australia-tackling-thegender-bias/8280186 Accessed 1/06/20

22. Hayakawa, S. I. and Hayakawa, A. R. 1990. Language in thought and action. Boston, USA: Houghton Mifflin Harcourt.

23. Hewitt, A. 2015. "Can you learn to lawyer online? A blended learning environment case study." The Law Teacher, 49(1): 92-121.

24. Holland, C. and Taylor, D. 2020. "Hopeful Perspectives: Incorporating Hope Theory in Australian Law Students' Academic Experience." In J. Marychurch, J. and A. Sifris (eds.). Wellness for Law: Making Wellness Core Business, Chatswood, Australia: LexisNexis Butterworths, pp. 111-122.

25. Jewel, L. A. 2008. "Bourdieu and American legal education: How law schools reproduce social stratification and class hierarchy." Buffalo Law Review, 56: 1155-1224.

26. Kritzer, H. 2013. "Law Schools and the Continuing Growth of the Legal Profession." Oñati Socio-legal Series, 3(3): 450-473.

27. Lane, C. 2020. "It's Your Journey: Overcoming the Adversity of Law School." In J. Marychurch, J. and A. Sifris (eds.). Wellness for Law: Making Wellness Core Business, Chatswood, Australia: LexisNexis Butterworths, pp. 43-44.

28. Larcombe, W., Tumbaga, L., Malkin, I., Nicholson, P., and Tokatlidis, O. 2013. "Does an Improved Experience of Law School Protect Students against Depression, Anxiety and Stress: An Empirical Study of Wellbeing and the Law School Experience of LLB and JD Students." Sydney Law Review, 45: 407-432.

29. Law Society of New South Wales. 2018, National Profile of Solicitors 2018 Report. 2018. https://www.lawsociety.com. $\mathrm{au} /$ sites/default/files/2019-07/2018\%20National\%20 Profile\%20of\%20Solicitors.pdf Accessed 1/06/2020

30. Litosseliti, L. 2003. Using Focus Groups in Research. London, UK: Bloomsbury.

31. MacDougall, C. and E. Fudge. 2001. "Planning and recruiting the sample for focus groups and in-depth interviews." Qualitative Health Research, 11 (1): 117-126. 
32. Manderson, D. and Turner, S. 2006. "Coffee house: Habitus and performance among law students." Law \& Social Inquiry, 31 (3): 649-676.

33. Marychurch, J. and Sifris, A. 2020. Wellness for Law: Making Wellness Core Business. Chatswood, Australia: LexisNexis Butterworths.

34. O'Loughlin, D., Sifris, A., and Batagol. B. 2020. "Wellness and Wellbeing at Monash University: The First Semester Law Experience". In J. Marychurch, J. and A. Sifris (eds.). Wellness for Law: Making Wellness Core Business, Chatswood, Australia: LexisNexis Butterworths, pp. 39-42.

35. Pinnington, A. H. and Gray, J. T. 2007. "The global restructuring of legal services work? A study of the internationalisation of Australian law firms." International Journal of the Legal Profession, 14 (2): 147-172.

36. Price, J. 2019. "Banking on a career at a top-tier law firm? Maybe you should consider your options." Sydney Morning Herald, Sydney, 6 September. https://www.smh.com.au/ national/banking-on-a-career-at-a-top-tier-law-firm-maybeyou-should-consider-your-options-20190905-p52oc5. html Accessed 1/06/20

37. Pryor, L. 2008. The Pinstriped Prison. Sydney, Australia: Picador Australia.

38. Roberts, E. 2020. "Pragmatic Concern for Law Student Wellbeing: Financial Security, Autonomous Learning and Compassionate Teaching." In J. Marychurch, J. and A. Sifris (eds.). Wellness for Law: Making Wellness Core Business, Chatswood, Australia: LexisNexis Butterworths, pp. 39-42.

39. Salt, B. 2016. "The exact remake: a statistical style analysis of six Hollywood films." New Review of Film and Television Studies, 14 (4): 467-486.

40. Social Research Centre. 2020. "Quality Indicators for Learning and Teaching." Melbourne. https://www.qilt.edu.au/ qilt-surveys/student-experience Accessed 1/06/2020
41. Sommerlad, H. 2007. "Researching and Theorizing the Processes of Professional Identity Formation." Journal of Law and Society, 34 (2): 190-217.

42. Swannie, B. 2020. "From Alienation to Empowerment: How Legal Educators Can Support Student Wellbeing." In J. Marychurch, J. and A. Sifris (eds.). Wellness for Law: Making Wellness Core Business, Chatswood, Australia: LexisNexis Butterworths, pp. 123-130/.

43. Truong, N. and Weill, N. 2012. "A decade after his death, French sociologist Pierre Bourdieu stands tall" The Guardian, London, 21 February. https://www.theguardian.com/ world/2012/feb/21/pierre-bourdieu-philosophy-mostquoted Accessed 11/10/18

44. Turner, S. and Manderson, D. 2007. "Socialisation in a space of law: student performativity at 'Coffee House' in a university law faculty." Environment and Planning D: Society and Space, 25(5): 761-782.

45. Wacquant, L. 1989. "Towards a Reflexive Sociology: A Workshop with Pierre Bourdieu." Sociological Theory, 7(1) Sociological Theory, 7(1): 26-63.

46. Webb, J., Schirato, T., and Danaher, G. 2002. Understanding Bourdieu. Thousand Oaks, USA: SAGE Publications.

47. Yau, B., Catanzariti, D., and Atkinson, J. 2019. "The Information Gap: A comparative study of the paradigms shaping perceptions of career success for law undergraduates and professional legal training students in Australia and the latent implications of non-professional legal career opportunities for law graduates in England.' In R. Field and C. Strevens (eds.) Educating for Well-Being in Law, Abingdon, UK: Routledge, pp. 74-88.

48. You've Entered Law Land, "Legal clerkships: what are they, and why are they important?" 22 June 2015. http:// youveenteredlawland.com/legal-clerkships-what-arethey-and-why-are-they-important/ Accessed 2/12/18. 